\title{
Analysis impact of construction site vibrations propagated through the ground on a selected residential building and its residents
}

\author{
Michal BUKALA ${ }^{1}$ (ORCID ID: 0000-0002-4172-7754) \\ Ryszard CHMIELEWSKI ${ }^{2}$ (ORCID ID: 0000-0001-5662-9180) \\ Andrzej CHYLA ${ }^{1}$ (ORCID ID: 0000-0001-6647-2375) \\ Leopold KRUSZKA ${ }^{2}$ (ORCID ID: 0000-0001-5129-2531) \\ Pawel OSTATEK ${ }^{1}$ (ORCID ID: 0000-0002-1085-3985) \\ Kamil SOBCZYK ${ }^{2}$ (ORCID ID: 0000-0002-5929-757X) \\ ${ }^{1}$ Svantek Sp. z o.o., 81 Strzygłowska Str., 04-872 Warsaw, Poland \\ ${ }^{2}$ Military Univ. of Technology, Dept. of Military Engineering and Military Infrastructure, 2 Kaliski Str., 00-908 Warsaw, Poland \\ corresponding author: kamil.sobczyk@wat.edu.pl
}

\begin{abstract}
An analysis of the harmful effects of vibrations generated as a result of works involving construction site equipment and propagated to an adjacent building and its users through the ground was carried out within the scope of this paper. Mechanical vibrations were generated during construction works by a pneumatic drill and a backhoe loader in the north east section of the $2^{\text {nd }}$ line of the Warsaw Metro. The vibrations were assessed pursuant to the requirements specified in the Polish PN-B-02170:2016-12 standard and compared with the standard threshold values. The research methodology, taking into account a description and location of the measurement site and specification of the measurement apparatus, is also presented.
\end{abstract}

Keywords: vibrations, ground, impact on a building.

Access to the content of the article is only on the bases of the Creative Commons licence CC BY-NC-ND 4.0

Please, quote this article as follows:

Bukała M. et al., Analysis impact of construction site vibrations propagated through the ground on a selected residential building and its residents, Engineering Expert, p. 16-23, No. 1, 2020, DOI: 10.37105/enex.2020.1.1.03

\section{Introduction}

Today, to accommodate the growing populations of cities such as Kraków, Gdańsk or Warsaw, continual construction works are an inherent element of large urban conurbations. Increasing numbers of office buildings and multi-family residential buildings require ever more urban infrastructure which residents rely on each and every day. Roadworks for better bus and tram access never seem to end. Works on extending the $2^{\text {nd }}$ line of the Warsaw Metro by a number of additional stations are also underway. This is driven by public sector interest and the residents' growing demand for this type of public transport. In an urban setting, minimising the risk to people and property at every stage of a construction investment project is an important factor. Various methods are used at different metro tunnel planning, design and construction stages in order to minimise the risk of negative impact (damage to nearby buildings, for example). The above-ground impact caused by vibrations generated by machinery working on underground structures such as a metro tunnel has to be investigated. A better understanding of that phenomenon is particularly important in an urban setting. Furthermore, in today's cities with a dense urban core, works involving dynamic compaction techniques or vibro processes have to be undertaken in very close proximity to other buildings. This entails the need to 
regularly monitor compliance with the acceptable vibration emission levels, and in particular for residential buildings, as these may be susceptible even to low vibration magnitudes. Ground vibrations exceeding the acceptable parameters, propagated by the ground to the urban environment (such as buildings) will have a tendency to generate deformations (Yuan et al., 2011), cracks on surface structures, and may cause walls and floors to shake (Connolly et al., 2016), (Yang et al., 2018). Any potential analyses should not overlook the impact of vibrations on people within those buildings residents may be exposed to dynamic effects generated by underground works, but also by aboveground and underground factors that constitute background vibrations at different frequency ranges (Vladimir et al., 2017). Building diagnostics and design increasingly call for the above effects to be taken into account, together with a verification of whether building requirements have been met in terms of vibration comfort for individuals in those buildings (Kawecki and Kowalska-Koczwara, 2011).

Problems associated with a negative impact of harmful vibrations generated by construction works is significant, as these vibrations are propagated from the ground to structural and finishing elements of buildings (both those being designed and already in place). These problems have been the subject of numerous research papers (Kawecki and Stypuła, 2009), (Tobita and Fukuwa, 2009), (Hashad, 2015), (Chmielewski et al., 2018), (Khabbaz et al., 2019) or (Pachla et al., 2019). Together with the decreasing availability of construction sites in urban areas and continual road building (both in cities and rural areas) aiming to improve traffic accessibility, more and more areas are experiencing these vibrations.

There are two standards that can be applied to assess the negative impact of vibrations in the vicinity of a construction site (including those generated by construction works and their impact on buildings):

- the German DIN 4150-3 'Structural Vibration Part 3: Effects of vibration on structures (in German)';

- the Polish PN-B-02170: 2016-12 'Assessment of the harmfulness of vibrations transmitted through the ground onto buildings (in Polish)'.

The Polish standard facilitates a more comprehensive assessment of the situation. It relies on the dynamic impact scale (SWD) for two types of buildings:

- SWD-I - small buildings with a compact footprint and up to two storeys high;

- SWD-II - buildings with a maximum of five storeys, which are smaller than twice the width.

The Polish PN-B-02170: 2016-12 standard based on a graph of acceleration amplitude plotted against frequency was used for the needs of this paper. The graph was divided into five vibration load zones:

- Zone I - vibrations imperceptible to a building;

- Zone II - vibrations discernible by a building's finishing elements (initial cracks in plaster and mortar) resulting in accelerated wear and tear of a building, but not harmful to its load bearing structure;

- Zone III - vibrations harmful to a building's load bearing structure, resulting in local hairline cracks and cracks to structural and load bearing elements, including crumbling of plaster and mortar, which weakens the load bearing structure, its integrity, and its resistance to subsequent dynamic factors;

- Zone IV - vibration load very harmful to a building, posing a safety risk within the scope of human habitation on account of numerous cracks and local damage, including destruction of masonry partitions and other individual construction and structural building elements, risk of suspended items falling, plaster crumbling from ceilings, ceiling beams dislodging from supports, etc.;

- Zone V - vibrations cause a risk of a building collapse, the building cannot be used.

This paper presents an analysis and evaluation of the harmful impact of vibrations, based on measurements of a selected building in a highly urbanised area in the vicinity of the north-east metro line construction site along the V20 plant room section. The research aimed to determine the 
magnitude of vibrations generated at the construction site and to compare these with acceptable levels as specified in the standard.

\section{Building specification}

The building comprising the subject-matter of the research is located on the corner of ul. Gilarska and ul. Łokietka. Its address is ul. Gilarska 35A, Warsaw (marked in red on the map - Fig. 1a and Fig. $1 \mathrm{~b}$. It is located in the north-east section of the 2nd line of the Warsaw Metro. It is a masonry building, with two above-ground storeys (see Fig. 2). The analysed vibrations are generated by construction site equipment: a pneumatic drill and a backhoe loader.

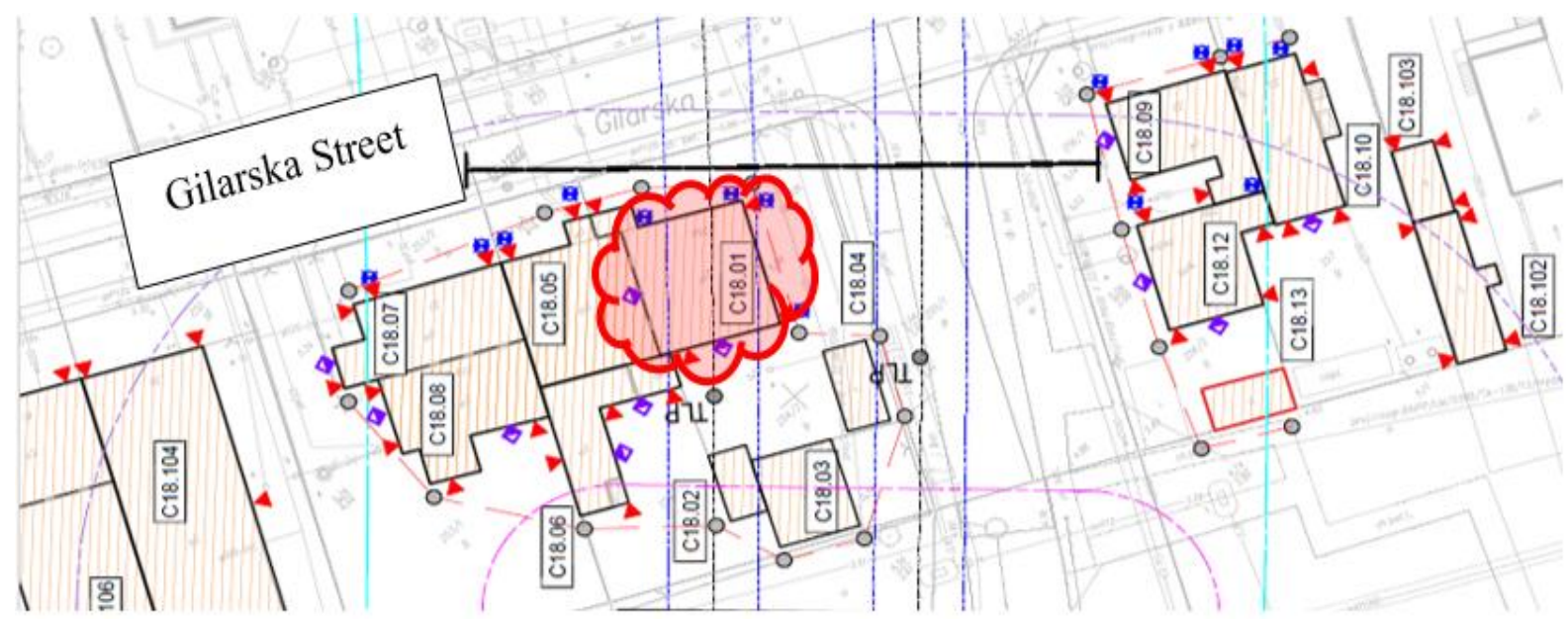

Fig. 1a. Building location (marked in red on the map).

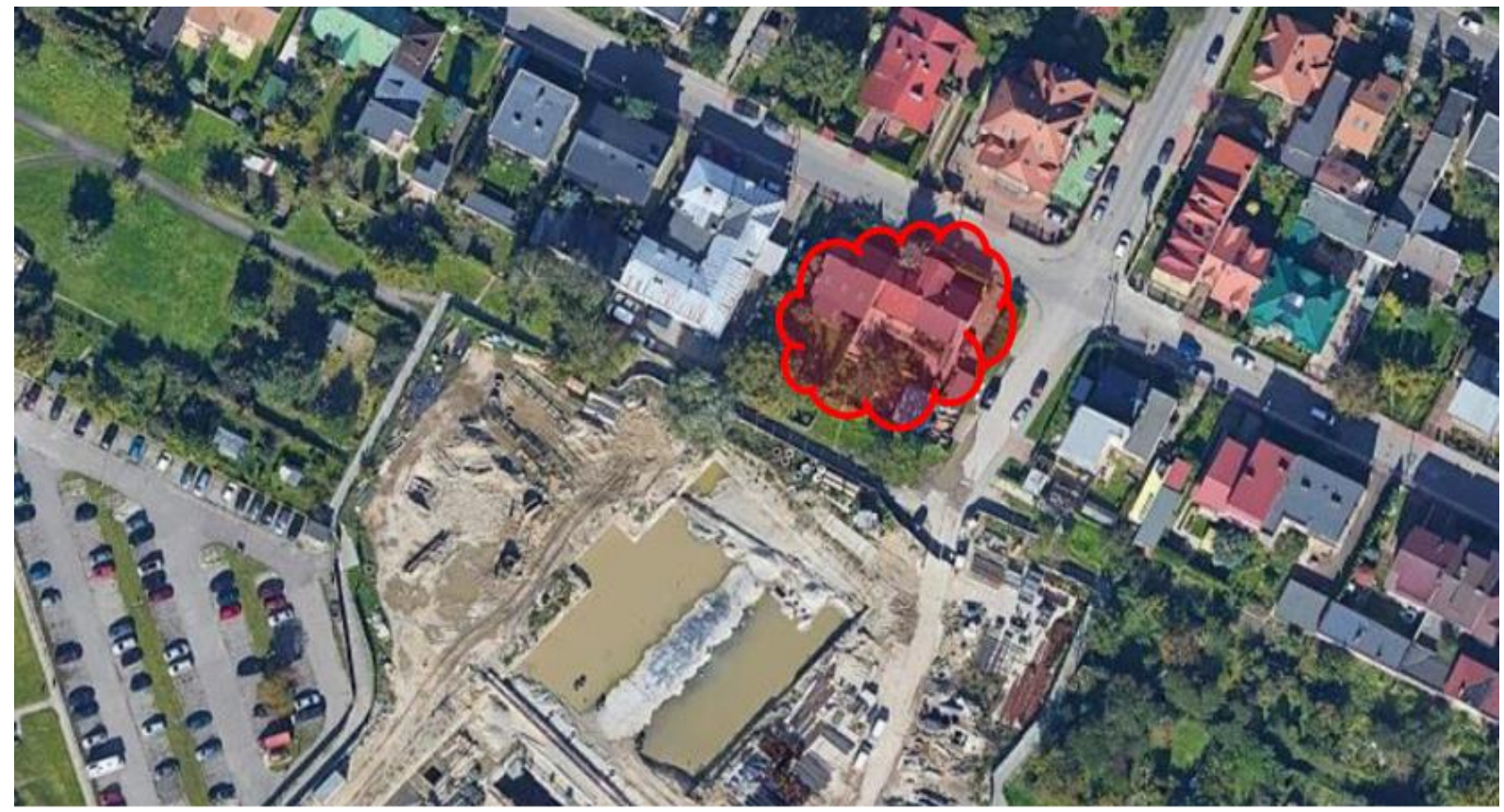

Fig. 1b. Building location (marked in red on the map). 


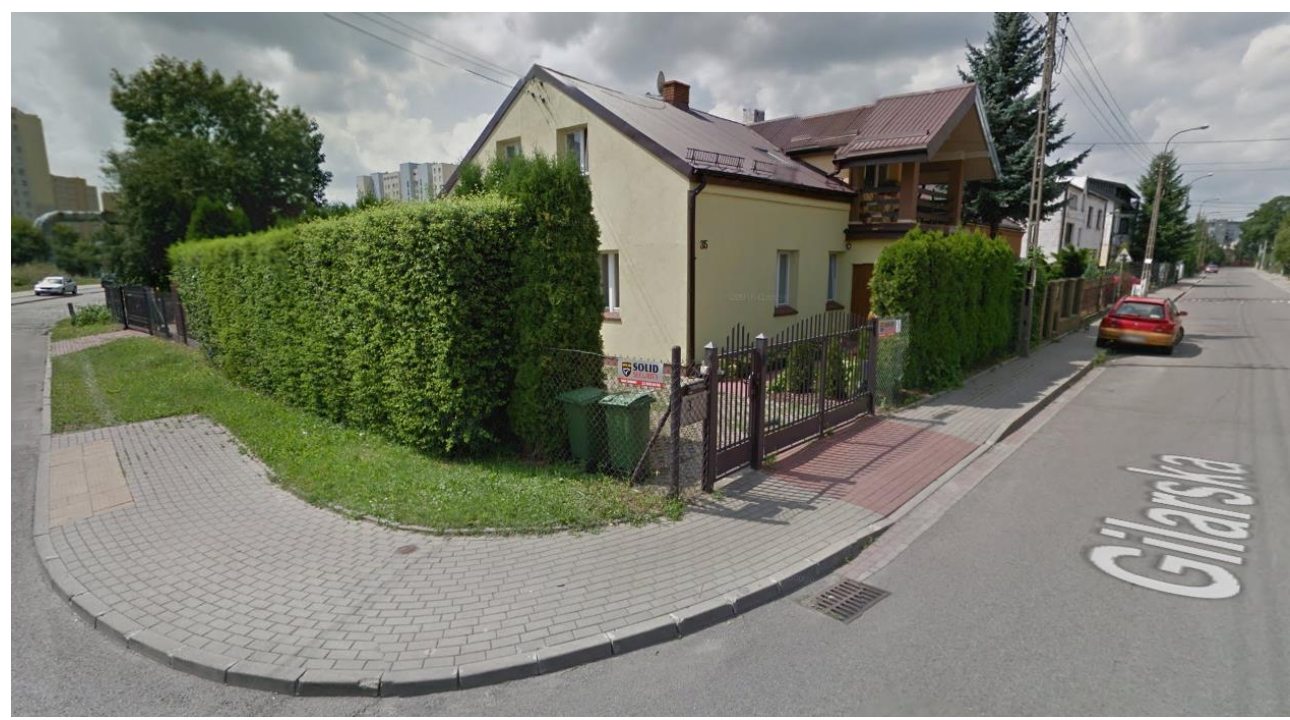

Fig. 2. View of the building.

\section{Research methodology}

The Polish PN-B-02170: 2016-12 standard was used to perform a reliable analysis of the impact of vibrations generated by construction site equipment on the building in question. The building complies with the requirements specified for the application of the SWD-I scale - small buildings with a compact footprint and up to two storeys high. The testing entailed a measurement of vibration acceleration along perpendicular $\mathrm{X}$ and $\mathrm{Y}$ axes as a function of time. A $750 \mathrm{~Hz}$ sampling frequency was used to capture data (including the useful $375 \mathrm{~Hz}$ frequency band). Discrete events were selected in order to compile results of vibration acceleration as a function of time. The peak value spectrum in the 1 to $100 \mathrm{~Hz}$ frequency range was determined in strict compliance with the Polish PN-B-02170: 2016-12 standard.

The following measuring apparatus and equipment was used in the vibration testing process:

- SVAN 958A No. 3668 vibration level meter (see Fig. 3) together with DYTRAN SV 84 No. E5591 vibration accelerometer (calibration certificate 707/10/2019 of 2019-08-22);

- SV111 No. 30596 vibration calibrator (calibration certificate 628/06/2018 of 2018-08-22);

- SVAN PC++ and MS Excel software;

- accessories and cabling.

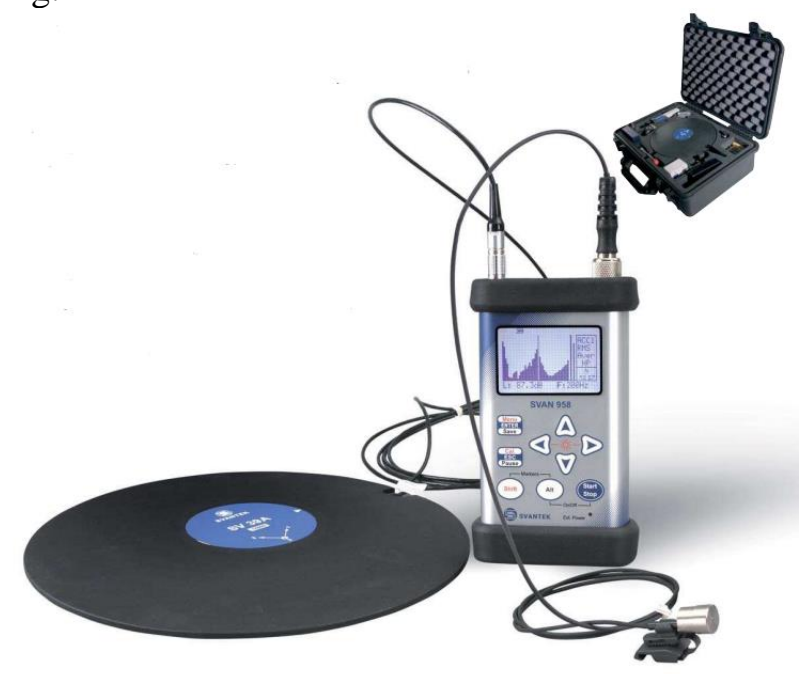

Fig. 3. SVAN 958A vibration level meter. 
Measurements were taken at a single measurement point P1 with the following coordinates: $52^{\circ} 16^{\prime}$ $39.8^{\prime \prime} \mathrm{N}$ and $21^{\circ} 03^{\prime} 32.5^{\prime \prime} \mathrm{E}$ (location of $\mathrm{P} 1$ marked in green in Fig. 4). The measurement point was selected to lie approximately $20 \mathrm{~m}$ from the source of vibrations (marked in orange in Fig. 4) generated by ongoing operation of construction site equipment: a pneumatic drill and a backhoe loader.

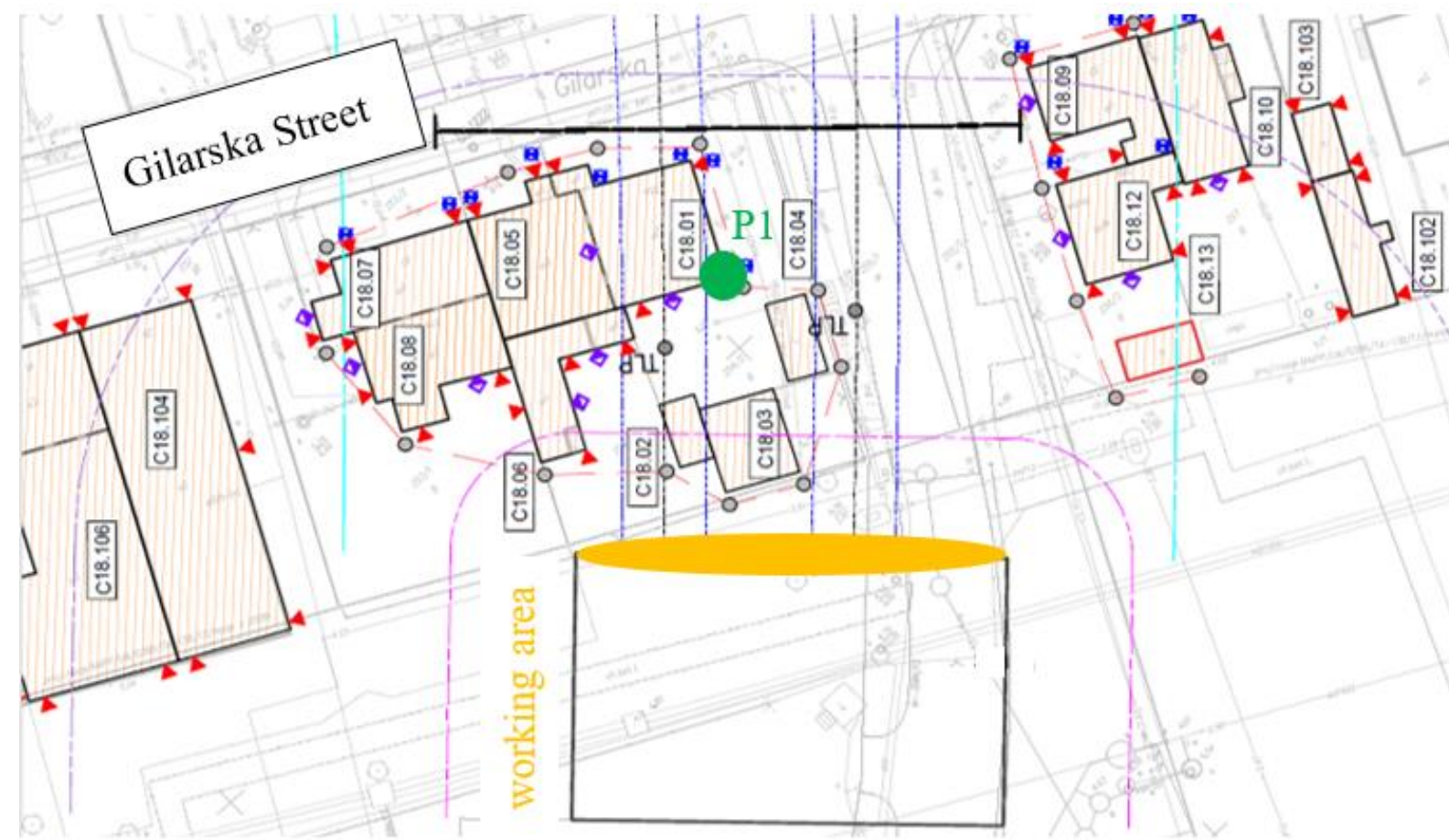

Fig. 4. Location of measurement point P1 (marked in green) and construction site equipment operation area (marked in yellow).

Prior to commencing tests, the SVAN 958A vibration level meter should be calibrated - the results of the calibration test are shown in Table 1.

Table 1. SVAN 958A No. 36683 meter vibration calibration.

\begin{tabular}{|c|c|c|c|c|c|}
\hline \multirow{2}{*}{ Measuring instrument } & \multirow{2}{*}{$\begin{array}{c}\text { Time of vibration cali- } \\
\text { bration }\end{array}$} & \multicolumn{2}{|c|}{$\begin{array}{c}\text { Result of vibration calibration } \\
{\left[\frac{m}{s^{2}}\right]}\end{array}$} & \multirow{2}{*}{$\begin{array}{c}\text { Reference value } \\
{\left[\frac{m}{s^{2}}\right]}\end{array}$} \\
\cline { 3 - 5 } & & Ch1 & Ch2 & Ch3 & \multirow{2}{*}{0.99} \\
\hline \multirow{2}{*}{ SVAN 958A No. 36683 } & Prior to measurement & 0.98 & 1.02 & 0.98 & \\
\cline { 2 - 5 } & After measurement & 0.98 & 1.02 & 0.98 & \\
\hline
\end{tabular}

The test preparation procedure also entailed a measurement of the meteorological conditions - the results are shown in Table 2. 
Table 2. Meteorological conditions measured prior to testing.

\begin{tabular}{|c|c|c|c|}
\cline { 2 - 4 } \multicolumn{1}{c|}{} & Maximum values & Minimum values & $\begin{array}{c}\text { Mean } \\
\text { values }\end{array}$ \\
\hline Measurement height $[\mathrm{m}]$ & \multicolumn{2}{|c|}{3.5} & 2 \\
\hline Ambient temperature $\left[{ }^{\circ} \mathrm{C}\right]$ & 3 & 1 & 994 \\
\hline Atmospheric pressure $[\mathrm{hPa}]$ & 994 & 994 & 3.9 \\
\hline Relative humidity $[\%]$ & 85 & 0.0 & \\
\hline Wind speed $[\mathrm{m} / \mathrm{s}]$ & 4.8 & - & 80 \\
\hline Comments & \multicolumn{2}{|c}{} \\
\hline
\end{tabular}

\section{Test results and analysis thereof}

Table 3 shows the results of vibration measurements in the form of peak vibration acceleration values $a_{\text {peak }}$ transferred through the ground to the building at measurement point P1 for perpendicular $\mathrm{X}$ and $\mathrm{Y}$ axes in the 1 to $100 \mathrm{~Hz}$ frequency range. Under the employed test methodology, for a 95\% confidence interval the measurement results are subject to expanded uncertainty of $U_{95}=10.4 \%$ for a coverage factor of $k=2$.

Table 3. Vibration measurement results at point $\mathrm{P} 1$.

\begin{tabular}{|c|c|c|}
\hline \multirow{2}{*}{$\mathrm{f}[\mathrm{Hz}]$} & \multicolumn{2}{|c|}{$a_{\text {peak }}\left[\frac{m}{s^{2}}\right]$} \\
\cline { 2 - 3 } & Peak vibration acceleration values \\
\hline 1 & $5.63 \mathrm{E}^{-04}$ & $7.23 \mathrm{E}^{-04}$ \\
\hline 1.25 & $6.74 \mathrm{E}^{-04}$ & $6.86 \mathrm{E}^{-04}$ \\
\hline 1.6 & $7.07 \mathrm{E}^{-04}$ & $8.84 \mathrm{E}^{-04}$ \\
\hline 2 & $6.55 \mathrm{E}^{-04}$ & $8.25 \mathrm{E}^{-04}$ \\
\hline 2.5 & $6.65 \mathrm{E}^{-04}$ & $7.59 \mathrm{E}^{-04}$ \\
\hline 3.15 & $6.30 \mathrm{E}^{-04}$ & $7.74 \mathrm{E}^{-04}$ \\
\hline 4 & $6.49 \mathrm{E}^{-04}$ & $7.83 \mathrm{E}^{-04}$ \\
\hline 5 & $9.97 \mathrm{E}^{-04}$ & $8.47 \mathrm{E}^{-04}$ \\
\hline 6.3 & $2.05 \mathrm{E}^{-03}$ & $1.47 \mathrm{E}^{-03}$ \\
\hline 8 & $3.40 \mathrm{E}^{-03}$ & $1.91 \mathrm{E}^{-03}$ \\
\hline 10 & $2.85 \mathrm{E}^{-03}$ & $4.94 \mathrm{E}^{-03}$ \\
\hline
\end{tabular}

\begin{tabular}{|c|c|c|}
\hline \multirow{2}{*}{$\mathrm{f}[\mathrm{Hz}]$} & \multicolumn{2}{|c|}{ Peak vibration } \\
\cline { 2 - 3 } & acceleration values $a_{\text {peak }}\left[\frac{m}{s^{2}}\right]$ \\
\hline 12.5 & $1.28 \mathrm{E}^{-03}$ & $\mathrm{Y}$ axis \\
\hline 16 & $2.14 \mathrm{E}^{-03}$ & $2.23 \mathrm{E}^{-03}$ \\
\hline 20 & $2.24 \mathrm{E}^{-03}$ & $2.17 \mathrm{E}^{-03}$ \\
\hline 25 & $1.61 \mathrm{E}^{-03}$ & $1.90 \mathrm{E}^{-03}$ \\
\hline 31.5 & $6.76 \mathrm{E}^{-04}$ & $1.38 \mathrm{E}^{-03}$ \\
\hline 40 & $6.95 \mathrm{E}^{-04}$ & $1.83 \mathrm{E}^{-03}$ \\
\hline 50 & $6.55 \mathrm{E}^{-04}$ & $7.50 \mathrm{E}^{-04}$ \\
\hline 63 & $1.99 \mathrm{E}^{-03}$ & $5.49 \mathrm{E}^{-04}$ \\
\hline 80 & $9.09 \mathrm{E}^{-04}$ & $1.38 \mathrm{E}^{-03}$ \\
\hline 100 & $4.62 \mathrm{E}^{-04}$ & $9.71 \mathrm{E}^{-04}$ \\
\hline
\end{tabular}

Pursuant to the Polish PN-B-02170:2016-12 standard and using the SWD-I scale, we have determined that the $a_{\text {peak }}$ vibration acceleration of the measured vibrations lie within the scope of zone I on the SWD-I scale. For the $\mathrm{X}$ axis, subject to frequency measurement at $f_{x}=8 \mathrm{~Hz}$, the peak vibration acceleration is $a_{\max , \mathrm{X}}=3,40 E^{-04} \frac{\mathrm{m}}{\mathrm{s}^{2}}$. For the $\mathrm{Y}$ axis, subject to frequency measurement at $f_{y}=10 \mathrm{~Hz}$, the peak vibration acceleration is $a_{\mathrm{max}, \mathrm{Y}}=4,94 E^{-03} \frac{\mathrm{m}}{\mathrm{s}^{2}}$. The a_peak measured vibration acceleration values subject to the SWD-I scale (at frequencies between 1 and $100 \mathrm{~Hz}$ ) are shown in Fig. 5 (for the $\mathrm{X}$ axis) and Fig. 6 (for the $\mathrm{Y}$ axis). 


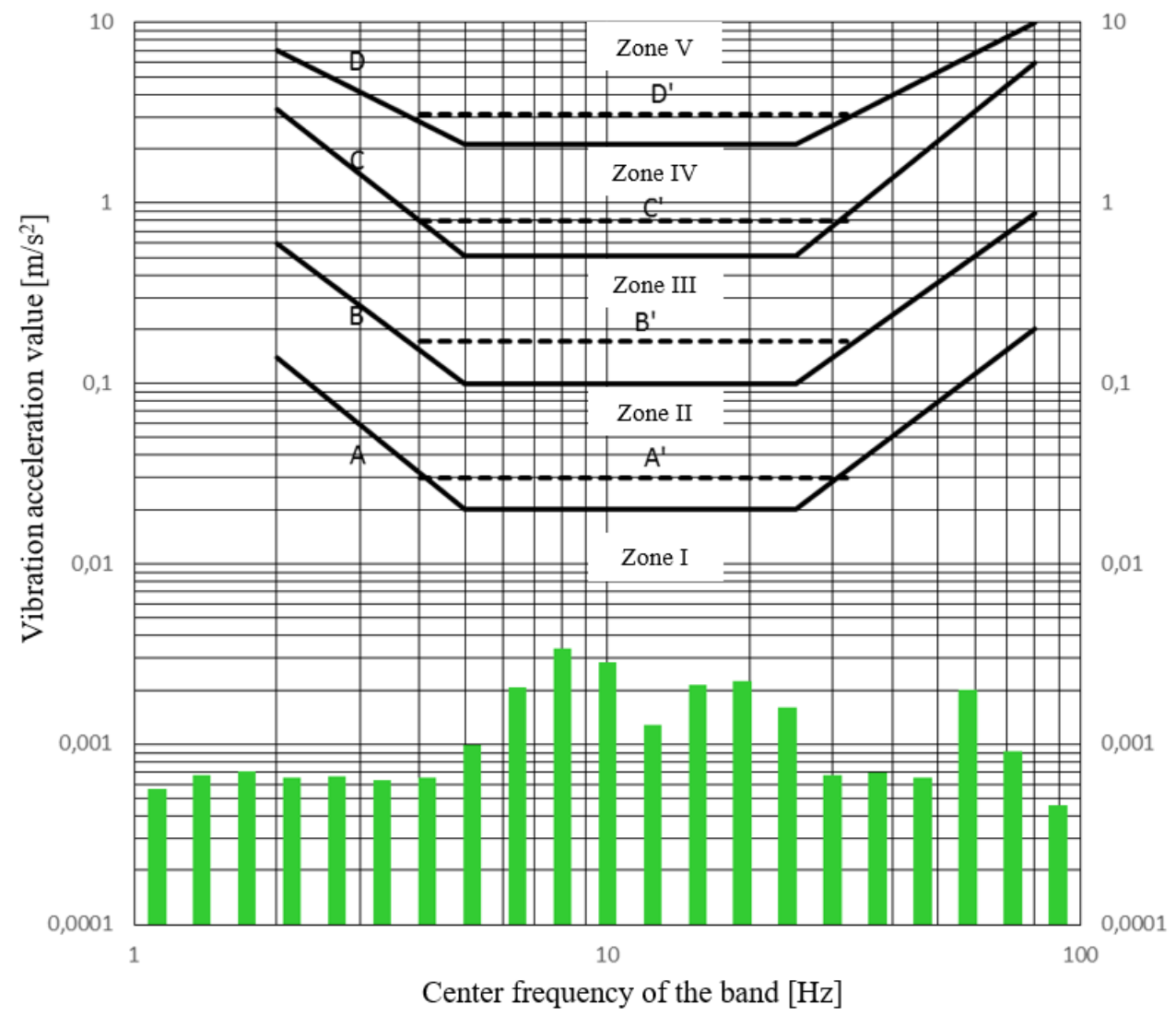

Fig. 5. Vibration acceleration values subject to the SWD-I scale for the $\mathrm{X}$ axis.

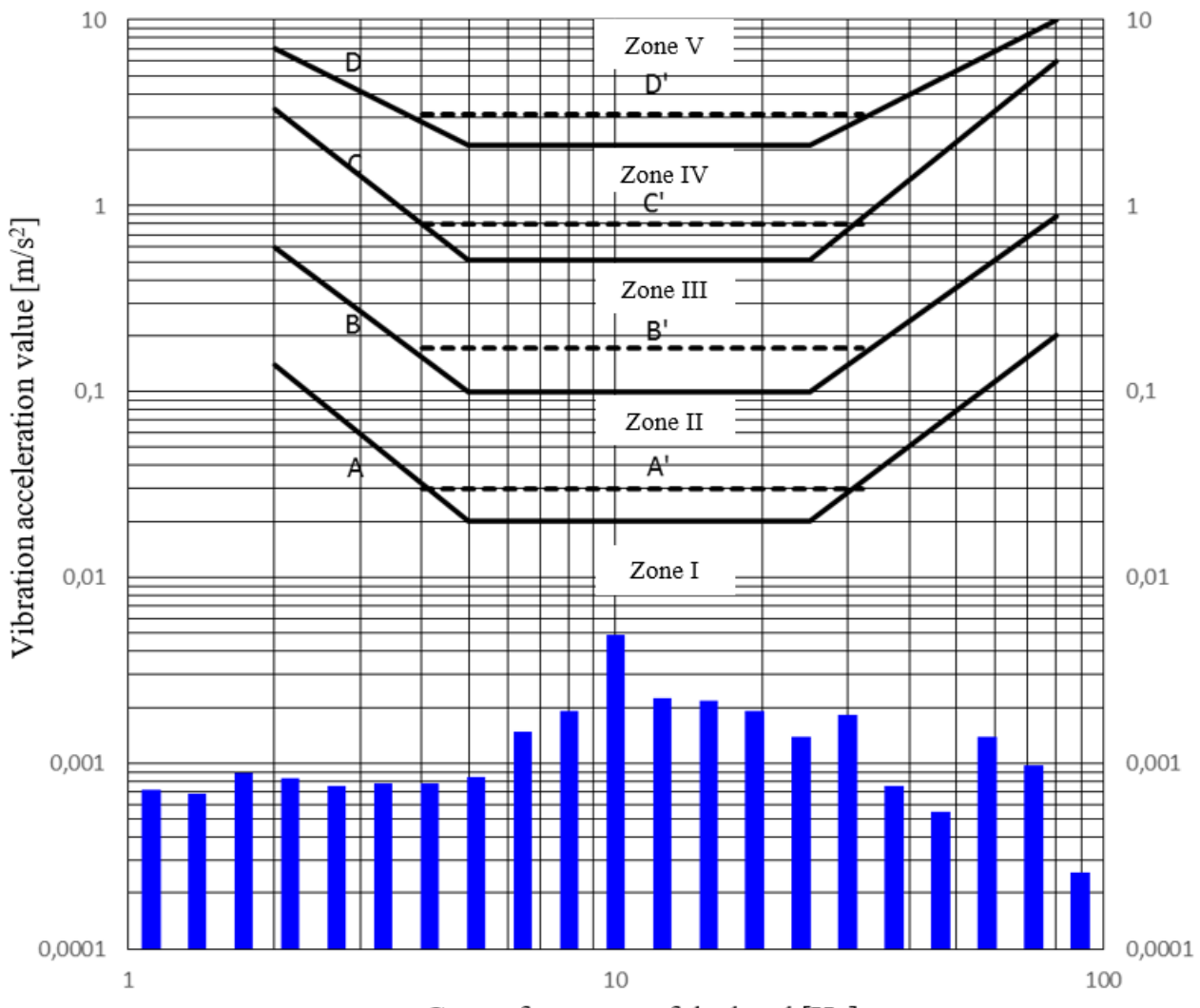

Center frequency of the band $[\mathrm{Hz}]$

Fig. 6. Vibration acceleration values subject to the SWD-I scale for the Y axis. 


\section{Summary}

This paper presents an analysis of the impact of mechanical vibrations generated by construction site works and propagated by the ground to an adjacent two-storey masonry building (located approximately $20 \mathrm{~m}$ from the source of the vibrations). The vibrations in question, generated by the operation of a pneumatic drill and a backhoe loader at the construction site of the $2^{\text {nd }}$ line of the Warsaw Metro (V20 plant room section), were tested subject to the SWD scale pursuant to the Polish PN-B-02170: 2016-12 standard within a frequency range of between 1 and $100 \mathrm{~Hz}$. The building complied with the requirements specified for the application of the SWD-I scale - small buildings with a compact footprint and up to two storeys high. No vibration acceleration was found in any of the vibration load zones. A maximum vibration acceleration value of $3,40 E^{-04} \frac{\mathrm{m}}{\mathrm{s}^{2}}$ was found for the X axis subject to an $8 \mathrm{~Hz}$ frequency and $4,94 E^{-03} \frac{\mathrm{m}}{\mathrm{s}^{2}}$ for the $\mathrm{Y}$ axis subject to a frequency of $10 \mathrm{~Hz}$. This means that all measurements made within the scope of the testing remained in zone I subject to the SWD-I scale (without even exceeding the lower zone I threshold A), and these vibrations should not be considered harmful for the adjacent building and its users subject to the analysis.

\section{Bibliography}

[1] Chmielewski, R., Chyla, A. and Kruszka, L. (2018). Analysis of harmful effects of vibrations and noise coming from construction works on existing buildings and people living in them (in Polish). Architektura i Budownictwo 17(3): 7989.

[2] Connolly, D. P., Marecki, G. P., Kouroussis, G., Thalassinakis, I. and Woodward, P. K. (2016). The growth of railway ground vibration problems - a review. Science of the Total Environment, 568, 1276-1282.

[3] German standard. DIN 4150-3. Structural Vibration Part 3: Effects of vibration on structures (in German).

[4] Hashad, A. (2015). Additional stresses on buildings induced by vibration effects. Water Science, Volume 29 (2): 134145.

[5] Kawecki, J. and Kowalska-Koczwara, A. (2011). Analysis of vibration influence on people in buildings in standards approach. Conference: Ravage Of The Planet III, Volume: 148.

[6] Kawecki, J. and Stypuła, K. (2009). Influence of vibrations generated by road works on historical structures (in Polish). Czasopismo Techniczne. Budownictwo, 106, 2-B, 183-189.

[7] Khabbaz, H., Gibson, R. and Fatahi, B. (2019). Effect of constructing twin tunnels under a building supported by pile foundations in the Sydney central business district. Underground Space, Volume 4 (4): 261-276.

[8] Pachla, F., Kowalska-Koczwara, A., Tatara, T. and Stypuła, K. (2019). The influence of vibration duration on the structure of irregular RC buildings. Bulletin of Earthquake Engineering.

[9] Polish standard. PN-B-02170: 2016-12. Assessment of the harmfulness of vibrations transmitted through the ground onto buildings (in Polish).

[10] Tobita, J. and Fukuwa, N. (2009). Ground vibration caused by tunnel construction and its effect on an electron microscope. Journal of Asian Architecture and Building Engineering, May 2009/111.

[11] Vladimir, S. and Ilya, T. (2017). To the question of vibration levels prediction inside residential buildings caused by underground traffic. Procedia Engineering, 176, 371-380.

[12] Yang, W., Cui, G., Xu, Z., Yan, Q., He, C., and Zhang, Y. 2018. An experimental study of ground-borne vibration from shield tunnels. Tunnelling and Underground Space Technology, 71, 244-252.

[13] Yuan, C., Wang, X., Wang, N. and Zhao, Q. (2012). Study on the effect of tunnel excavation on surface subsidence based on GIS data management. Procedia Environmental Sciences, 12, 1387-1392. 